\title{
Editorial
}

\section{Proceso editorial en tiempos de confinamiento}

\author{
Editorial process in times of confinement \\ Cleofé Genoveva Alvites Huamaní 1 \\ https://orcid.org/0000-0001-6328-6470 \\ Editor en jefe de la revista científica Hamut'ay \\ Universidad Alas Peruanas, Perú
}

\section{Cita Recomendada}

Alvites-Huamaní, C. (2020). Proceso editorial en tiempos de confinamiento. Hamut'ay, 8(1), 5-8

http://dx.doi.org/10.21503/hamu.v8i1.2231

\section{Introducción}

Cuando en el mundo se avizoraba el inicio de un nuevo año, con muchas expectativas y con la esperanza de dejar en el pasado el 2020, como un año funesto para todos. Aunque se había iniciado la vacunación en más de 50 países, la esperanza regresó y muchos pensaron que el tema de la pandemia pasaría a un segundo plano, lo cual no ha sido de esta manera, por el contrario, tanto los profesionales, empresarios, organización, instituciones y diversos profesionales tuvieron que reinventarse para seguir con sus metas, debido a que en muchos países el confinamiento continuaba y continúa, en algunos de manera restrictiva y en otros de manera intermitente.

Esta situación no ha sido ajena al campo editorial de las revistas científicas, sobre todo en el proceso editorial (Párraga, 2021), en el que es importante la interacción que se realiza con los autores, comité editorial y el editor en jefe de la revista para poder tomar las decisiones que implica publicar un número. Pero la situación nos obligó a continuar, sobre todo con la responsabilidad de seguir haciendo divulgación y visibilidad científica (Aguilar, 2020) y mantener informado a la academia, de cómo muchos profesionales de los diferentes campos han afrontado este contexto desde sus especialidades y de qué manera se han valido para seguir brindando los avances de la ciencia en todos los ámbitos (Gronvall, Waldhorn

\section{Introduction}

When the world was looking forward to the beginning of a new year, with many expectations and with the hope of leaving 2020 in the past, as a disastrous year for all, Although vaccination had started vaccination in more than 50 countries, hope returned and many thought that the pandemic issue would pass to the background, On the contrary, professionals, businessmen, organizations, institutions and various professionals had to reinvent themselves to continue with their goals, because in many countries the confinement continued and continues, in some in a restrictive manner and in others intermittently. This situation has not been alien to the editorial field of scientific journals, especially in the editorial process (Párraga, 2021), in which the interaction with the authors, editorial committee and the editor in chief of the journal is important in order to make the decisions involved in publishing an issue. But the situation forced us to continue, especially with the responsibility to continue making scientific dissemination and visibility (Aguilar, 2020) and to keep the academy informed of how many professionals from different fields have faced this context from their specialties and how they have used it to continue providing the advances of science in all areas (Gronvall, Waldhorn \& Henderson, 2006), especially in education, social and human sciences, 
\& Henderson, 2006), sobre todo en la educación, las ciencias sociales y humanas entre las que han tenido un cambio sustancial en sus actividades.

En este contexto, las tecnologías de la información y comunicación han sido un medio que ha servido para acercarnos y hacer soportable este problema de la no presencialidad y adaptarnos a esta nueva normalidad sin presencia física; y que el ciberespacio sea nuestra comunidad académica, nuestro entorno laboral, estudiantil y mucho más. Pues nos ha llevado a replantar nuestras actividades editoriales de una manera tanto sincrónica como asincrónica con la finalidad de seguir brindando el acceso abierto (Aguilar, 2020) a los hallazgos encontrados en las investigaciones que publican los investigadores.

\section{Proceso editorial en tiempos de confinamiento}

En tiempos en lo que la seguridad sanitaria es primordial a nivel mundial por la pandemia y el estar en confinamiento, el teletrabajo ha sido una alternativa para continuar realizando nuestras actividades laborales. Pero también ha incidido en el proceso editorial, ya que siendo necesario mostrar resultados de investigaciones realizadas entorno al virus y como estas han influenciado en la salud, muchas revistas se vieron obligadas a publicar pre-print (Romani, 2020) para dar visibilidad de manera pronta a temas de salud que eran necesarios mostrar los hallazgos de inmediato (Majumder \& Mandl, 2020).

En contraparte de lo mencionado, en otros ámbitos académicos, no ha sucedido lo mismo, ya que los investigadores habían dejado en espera muchos de sus estudios, por la complejidad que se vive, lo cual afectó de alguna manera que muchas revistas no contaran con los artículos suficientes y por ende no publicaran en el tiempo establecido.

A diferencia de las revistas que tenían sus líneas de investigación en salud tuvieron en exceso artículos sobre todo lo relacionado al SARCoV-02 (Horbach, 2020); aspecto que favoreció el incrementar la rapidez en la difusión de nuevo conocimiento (Párraga, 2021) en acceso abierto, incluso, hasta las grandes editoriales lo hicieron. among those that have had a substantial change in their activities.

In this context, information and communication technologies have been a means that has served to bring us closer and make this problem of non-presence bearable and adapt to this new normality without physical presence; and that cyberspace is our academic community, our work environment, our student environment and much more. This has led us to rethink our editorial activities both synchronously and asynchronously in order to continue providing open access (Aguilar, 2020) to the findings found in the research published by researchers.

\section{Editorial process in times of confinement}

In times when health security is paramount world wide due to the pandemic and being in confinement, teleworking has been an alternative to continue performing our work activities. But it has also affected the editorial process, since it is necessary to show results of research conducted around the virus and how these have influenced health, many journals were forced to publish preprints (Romani, 2020) to give visibility promptly to health issues that were necessary to show the findings immediately (Majumder \& Mandl, 2020).

In contrast to the above, in other academic fields, the same has not happened, since researchers had put many of their studies on hold, due to the complexity of the situation, which affected in some way that many journals did not have enough articles and therefore did not publish in the established time.

Unlike the journals that had their lines of research in health, they had an excess of articles on everything related to SARCoV-02 (Horbach, 2020); an aspect that favored an increase in the speed of dissemination of new knowledge (Párraga, 2021) in open access, and even the large publishers did so.

At a time when the world is facing this health crisis and all sectors of society are affected, access to scientific knowledge is essential, so journals and academic publishers must make this new 
En momentos en que el mundo enfrenta esta crisis de salud y que hay una afectación a todos los sectores de la sociedad, el acceso al conocimiento científico es fundamental, por lo que las revistas y los editores académicos deben hacer posible que estos nuevos conocimientos estén disponibles (Horbach, 2020) a todo los profesionales y no profesionales que les permitan una información clara y fidedigna.

$\mathrm{Al}$ respecto, hay que hacer hincapié que muchas de las revistas han brindado el acceso abierto a la diversidad de sus contenidos de manera inmediata y gratuita (Villca y Condori, 2020) a pesar de que estas revistas pertenezcan a editoriales de no acceso general, pero por la coyuntura de la pandemia se ha tenido esa flexibilidad.

Con el deseo de realizar la publicación del este primer número del 2021, aunque ha sido más de un año de pasar de una cuarentena, aislamiento y confinamiento en la que las autoridades universitarias, en nuestro caso, se vieron obligados a buscar las herramientas para que podamos continuar con nuestra labor realizando teletrabajo o trabajo remoto, la cual los editores también se han tenido que adaptar, junto con los otros miembros del equipo editorial como el corrector de estilo, traductor, diseñador, soporte técnico, comité editorial y científico y sobre todo los aportes de los pares evaluadores que cumplen una función muy loable en este proceso editorial (Blanco, 2012), a todos ellos nuestro agradecimiento por su ardua entrega y dedicación a la revista Hamut 'ay, y por lo cual le rendimos un homenaje a todos los pares evaluadores que han sido constantes por años en el apoyo a la revista.

\section{Referencias Bibliográficas}

Aguilar, M., (2020). La edición científica en tiempos de pandemia. Revista Diversitas - Perspectivas en Psicología, 16 (2), 29-30.

Blanco, C. (2012). Conocimiento del proceso editorial como ruta para ayudarnos a publicarle. Revista Colombiana de Gastroenterología, 27 (1), 5-6

Gronvall G.K., Waldhorn R.E., Henderson, D.A., (2006) The scientific response to a pandemic. knowledge available (Horbach, 2020) to all professionals and non-professionals to provide them with clear and reliable information.

In this regard, it should be emphasized that many of the journals have provided open access to the diversity of its contents immediately and free of charge (Villca and Condori, 2020) despite the fact that these journals belong to non-general access publishers, but due to the pandemic situation, this flexibility has been granted.

With the desire to publish this first issue of 2021, although it has been more than a year of going through a quarantine, isolation and confinement in which the university authorities, in our case, were forced to find the tools so that we can continue our work by teleworking or remote work, which the editors have also had to adapt, along with other members of the editorial team as the proofreader, translator, designer, technical support, editorial and scientific committee and above all the contributions of peer reviewers who play a very commendable role in this editorial process (Blanco, 2012), to all of them our thanks for their hard work and dedication to the journal Hamut'ay, and for which we pay tribute all the peer reviewers who have been constant for years in supporting the journal. 
PLoS Pathog 2(2), 9. https://doi.org/10.1371/ journal.ppat.0020009

Horbach, S. (2020). Pandemic Publishing: Medical journals drastically speed up their publication process for Covid-19. https://doi. org/10.1101/2020.04.18.045963

Romani F. (2020). Adaptación del proceso editorial de la Revista Peruana de Medicina Experimental y Salud Pública durante la pandemia COVID-19. Rev Peru Med Exp Salud Publica. 37(2), 193-194. https://doi.org/10.17843/rpmesp.2020.372.5954

Párraga, I, (2021). Urgencia en la comunicación de resultados de investigación durante una pandemia. Revista Clínica de Medicina de Familia, 14(1), 1-3.

Majumder, M.S. \& Mandl, K.D. (2020). Early in the epidemic: impact of preprints on global discourse about COVID-19 transmissibility. Lancet Glob Health, 8(5), 627-630.

https://doi.org/10.1016/S2214-109X(20)30113-3 Villca, J. L. y Condori, N. F. (2020) Adaptación del Proceso Editorial y la Importancia del Acceso Abierto durante la Pandemia del COVID-19. Revista Científica Ciencia Médica, 23(1) 4-5. https://doi.org/10.51581/rccm.v23i1.55 